\title{
“Groups Excluded from 'Representative' Household Surveys: An Analysis Based on Remittances Sent and Received in Vietnam”
}

\author{
by \\ Wade Donald Pfau \\ Associate Professor, National Graduate Institute for Policy Studies (GRIPS) \\ 7-22-1 Roppongi, Minato-ku, Tokyo, Japan 162-8677 \\ wpfau@grips.ac.jp \\ Tel: 81-3-6439-6225 Fax: 81-3-6439-6010 \\ and \\ Giang Thanh Long \\ Lecturer, National Economics University (NEU) \\ 207 Giai Phong Street, Hai Ba Trung District, Hanoi 10000, Vietnam \\ longgt@neu.edu.vn \\ September 2008
}

Corresponding Author: Wade Donald Pfau

Keywords: Vietnam; Remittances; Household Survey Design

JEL classification: D1, D63, F24

Acknowledgement: We thank the Univers Foundation for their financial support.

\begin{abstract}
The Vietnam Living Standard Surveys (VLSS) are supposed to be representative of the entire population in Vietnam. However, we uncover an anomaly that the amount of remittances received from domestic sources is significantly larger than the amount of remittances sent to domestic sources, implying that the survey is at least not representative of remittance senders. By further exploring a unique characteristic of the survey questions about remittances, we determine that, in particular, female and urban-dwelling remittance senders are underrepresented in the survey.
\end{abstract}




\section{Introduction}

The Vietnam Living Standard Surveys (VLSS) in 1992/93 and 1997/98, which were conducted by the General Statistics Office of Vietnam (GSO) along with other international agencies as a part of the World Bank’s Living Standard Measurement Surveys, are assumed to be representative of the entire Vietnamese population (Dollar and Kraay, 2004; Cox, 2004). However, this letter uncovers an anomaly in the surveys, that is, the identified amount of remittances received by households from domestic sources is significantly larger than the amount these same households send to others in Vietnam. This should not be the case, because if the surveys provide a representative sample of the entire Vietnamese population, the amount of remittances sent from domestic households to other domestic households should be approximately equal to the amount received by domestic households from other domestic households. Recently, Pincus and Sender (2008) have argued that the survey design methodology leads to the exclusion of many internal migrants and cannot be considered representative, particularly for a country undergoing rapid economic transformation and urbanization. They argue that migrants are missing from the survey design both because of the passing time between drawing sample lists and conducting interviews, and because many migrants are not legally registered at their new locations. The contribution of this letter is that, by further exploring the questions about remittances in the surveys, we are able to use the surveys themselves to confirm that particular groups are underrepresented and thus to provide direct empirical support for the conclusions of Pincus and Sender (2008). Our results demonstrate that female and urban-dwelling remittance senders are underrepresented in the surveys. 


\section{Data}

We use the Vietnam Living Standard Surveys (VLSS) for the years 1992/93 and 1997/98. ${ }^{1}$ Detailed descriptions of these surveys can be found in numerous sources, such as Grosh and Glewwe (1998) and World Bank (2000 and 2001). The 1992/93 survey includes 4,800 households with 24,068 individuals, and the 1997/98 survey includes 6,002 households with 28,633 individuals. The surveys include questions about individual characteristics, as well as household level information about income, expenditures, poverty, and housing conditions. For this letter, we are mainly interested in the questions about remittances, which are defined in the surveys as the amount of money and monetary value of in-kind benefits received by a household from people not living in the household, such as family and friends, which do not require repayment.

\section{Methodological Approach}

This letter exploits an aspect of the surveys which allows a glimpse into the excluded households. The important survey feature is that for each interviewed household, questions are asked about the remittances received and sent by the household. For remittances received, the information includes which member received it, the relationship of the remittance sender to the receiver, the gender of the sender (only in 1997/98), where the sender lives and whether the location is urban or rural. The corresponding information is available for remittances sent. These questions allow us to obtain limited information about the senders and receivers of remittances, respectively, who are people that may or may not otherwise be in a position to show up in the sample universe. It must be clear that

\footnotetext{
${ }^{1}$ Household surveys are also available for 2002, 2004, and 2006, but the information about remittances is much more limited in the later surveys, which prevents us from pursuing our research objectives.
} 
the survey is one-way in the sense that while we have detailed survey questions about the individuals in the dataset who comprise the receivers and senders of remittances, we only have the limited information just described for the other half of the remittance transaction, the senders and receivers of those remittances, respectively. Nonetheless, this aspect of the survey allows us to make comparisons between two pairings, as shown in Table 1. By comparing the survey's remittance recipients to those who receive remittances from the survey's remittance senders, and by comparing the survey’s remittance senders to those who send remittances to the survey’s remittance recipients, we are able to observe the differences between the groups and obtain a greater understanding about those who have been excluded from the sampling universe.

\section{// Table 1 About Here //}

\section{Results and Implications}

Table 2 shows the aggregate flow of domestic remittances in both surveys. To the extent that the surveys are representative of the entire Vietnamese population, the ratio of remittances received to remittances sent by survey members should be approximately one, or in other words, the reported amount of remittances received by Vietnamese households from other Vietnamese households should be approximately equal to the amount of remittances reported to be sent to the same. But this is not the case. In the 1992/93 survey, the amount of remittances received from domestic sources was 89 percent larger than the amount sent. Breaking this down further, remittances received from households within the same province were 99 percent larger than remittances sent to households within the same province, and remittances received from another province were 72 percent larger. In the 
1997/98 survey, the differences do become smaller, but it is still the case that the remittances received from domestic households were 46 percent larger than the remittances sent to domestic households.

\section{// Table 2 About Here //}

What could explain the gap between remittances sent and remittances received? One possible explanation is the underreporting of remittance amounts. But if this were the case, it would seem more plausible that people would underreport the amount of remittances they receive, rather than the amount they send, which is the opposite of our findings. The other possibility is that the survey does not provide a proper representative sample of the entire population, and in fact a large number of remittance senders may be missing. In particular, if many people who send remittances are migrants, then it may be difficult to include them in the survey. Pincus and Sender (2008) argue that this point is quite important in Vietnam's case. This would provide a rather feasible explanation for why the amounts of remittances received are so much larger than the amounts sent. Note that while recipients are better represented in the survey than senders, we cannot say that recipients are fully represented, because some missing migrants may also receive remittances. We now analyze who may be underrepresented in the survey.

\section{// Table 3 About Here //}

Table 3 provides further analysis of the situation in an attempt to gain insight about who may be missing from the survey. For gender and urban/rural location, we compare the results from the two different comparison groups shown in Table 1. The gender of the matched remittance counterpart from outside the survey is only available in the 1997/98 
survey. For remittances received, we find that females received 50.8 percent of the total domestic remittances in the survey data, but only 38.3 percent of the domestic remittances in the counterpart data for the receivers matched to survey senders. Because the data on survey recipients is more complete, this result implies that people who send remittances to females are missing from the data. Next, because the survey data shows that females send only 32.8 percent of remittances, but the more complete corresponding questions about remittance receipt show that females send 42 percent of the remittances, we can confirm that female remittance senders are missing from the survey as well. This same analysis can be applied to the urban/rural location for both survey years as well, as we consistently find that urban residents are underrepresented both a destination and source of remittances. In particular, the largest distinctions occur for urban remittance senders, as the senders matched to receivers show 26 percent points more of the remittance share in 1992/93 and 19.7 percent points more in 1997/98. This means that urban remittance senders are quite underrepresented in the survey.

A number of implications follow from this analysis. For instance, if many urban migrants are missing from the data, then estimates of urban poverty and urban transformation will not present the complete story. Likewise, Cox (2004) finds that households identified as net recipients of remittances have lower pre-remittance incomes than households identified as net senders, and argues that remittances help to promote equality because the difference in incomes provides an unbiased estimate of the mean difference since the survey is representative. But this result does not hold if the survey is 
not representative. Indeed, further research will be needed for any conclusions relying on the assumption that the data is representative.

\section{Conclusion}

By using the VLSS questions about remittances, we find that the domestic remittances received by households are larger than the remittances sent, which implies that a significant number of remittance senders are missing from the dataset. Exploring further, we find evidence that female and urban remittance senders are underrepresented in the survey data. Thus, we are able to use the VLSS surveys themselves to confirm that they are not entirely representative of the Vietnamese population. 


\section{References}

Cox, D., 2004, Private Inter-household Transfers in Vietnam, in: P. Glewwe, N. Agrawal, and D. Dollar, eds., Economic Growth, Poverty, and Household Welfare in Vietnam.

(World Bank, Washington, DC) 567-603.

Dollar, D. and A. Kraay, 2004, Trade, Growth, and Poverty, The Economic Journal 114, F22-F49.

Grosh, M. E. and P. Glewwe, 1998, Data Watch: The World Bank’s Living Standards Measurement Study Household Surveys, Journal of Economic Perspectives 12(1), 187-196.

Pincus, J. and J. Sender, 2008, Quantifying Poverty in Viet Nam: Who Counts?, Journal of Vietnamese Studies 3(1), 108-150.

World Bank, 2000, Vietnam Living Standards Survey (VNLSS), 1992-1993: Basic Information. (World Bank Poverty and Human Resources Division, Washington, DC) (updated from 1994 version).

World Bank, 2001, Vietnam Living Standards Survey (VNLSS), 1997-1998: Basic Information. (World Bank Poverty and Human Resources Division, Washington, DC). 
Table 1

Comparison Groups

\begin{tabular}{cc}
\hline Group in Survey & $\begin{array}{c}\text { Corresponding Group with Limited Information } \\
\text { from Outside Survey }\end{array}$ \\
\hline Remittance Recipients & $\begin{array}{c}\text { Those who receive remittances } \\
\text { from the survey's remittance senders }\end{array}$ \\
\hline Remittance Senders & $\begin{array}{c}\text { Those who send remittances } \\
\text { to the survey's remittance recipients }\end{array}$ \\
\hline
\end{tabular}


Table 2

Aggregate Flow of Domestic Remittances (in billions of Vietnamese dong)

\begin{tabular}{cccc}
\hline & Received & Sent & Ratio (Received / Sent) \\
\cline { 2 - 4 } & \multicolumn{3}{c}{1992 / 1993 } \\
\cline { 2 - 4 } Total Domestic Remittances & 2168 & 1147 & 1.89 \\
(Within Same Province) & 1449 & 729 & 1.99 \\
(Between Provinces) & 718 & 418 & 1.72 \\
\cline { 2 - 4 } & \multicolumn{3}{c}{$1997 / 1998$} \\
Total Domestic Remittances & 7580 & 5200 & 1.46 \\
(Within Same Province) & 4250 & 2400 & 1.77 \\
(Between Provinces) & 3330 & 2800 & 1.19 \\
\hline
\end{tabular}

Source: Own calculations from VLSS 1992/93 and 1997/98 
Table 3

Percentage of Domestic Remittances Received / Sent for Various Characteristics

\begin{tabular}{|c|c|c|c|}
\hline Characteristic & $\begin{array}{l}\text { Receive / } \\
\text { Send }\end{array}$ & Data Source & Percentage \\
\hline \multirow{4}{*}{$\begin{array}{l}\text { Females } \\
(1997 / 98)\end{array}$} & \multirow{2}{*}{ Receive } & Survey Receivers & 50.8 \\
\hline & & Receivers Matched to Survey Senders & 38.3 \\
\hline & \multirow{2}{*}{ Send } & Senders Matched to Survey Receivers & 42.0 \\
\hline & & Survey Senders & 32.8 \\
\hline \multirow{4}{*}{$\begin{array}{l}\text { Urban Residents } \\
(1992 / 93)\end{array}$} & \multirow{2}{*}{ Receive } & Survey Receivers & 47.6 \\
\hline & & Receivers Matched to Survey Senders & 42.3 \\
\hline & \multirow{2}{*}{ Send } & Senders Matched to Survey Receivers & 68.5 \\
\hline & & Survey Senders & 42.5 \\
\hline \multirow{4}{*}{$\begin{array}{l}\text { Urban Residents } \\
\text { (1997/98) }\end{array}$} & \multirow{2}{*}{ Receive } & Survey Receivers & 53.0 \\
\hline & & Receivers Matched to Survey Senders & 44.2 \\
\hline & \multirow{2}{*}{ Send } & Senders Matched to Survey Receivers & 77.0 \\
\hline & & Survey Senders & 57.3 \\
\hline
\end{tabular}

Source: Own calculations from VLSS 1992/93 and 1997/98 